\title{
A Sindhi Bhagat Song Associated with Kanvar Ram
}

\author{
Jyoti Garin | ORCID: 0000-0002-5751-6919 \\ Ph.D., INALCo: Institut National des Langues et Civilisations Orientales, \\ Paris, France \\ jyoti.garin@outlook.com
}

\begin{abstract}
This article presents a translation from the Sindhi oral tradition of bhagat. It originates in Sindh, Pakistan. Today it is practiced by Hindu narrators in post-Partition India. The song translated in this paper focuses upon Bhagat Kanvar Ram, who contemporary bhagat narrators mention frequently. This essay exemplifies his influence on the bhagat tradition in the areas of inspiration, authority, and performance style. It offers a glimpse of the dynamics of the live performances of oral texts.
\end{abstract}

\section{Keywords}

Sindhi folklore - bhagat - Sindhi folk song - Sindhi folk theatre performance - Bhagat Kanvar Ram - martyr

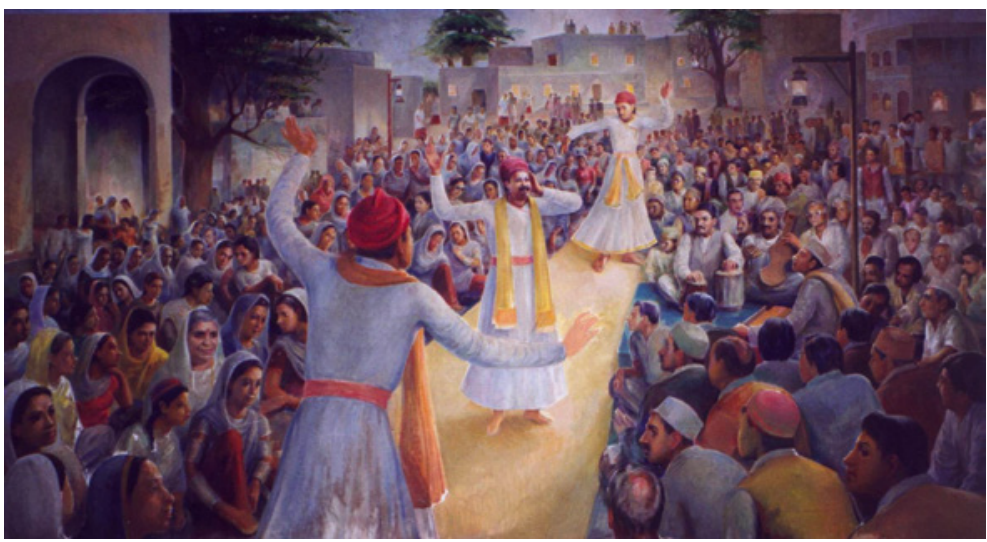

FIGURE 1 The bhagat performance by Dewan Bhojwani from the Sita Sindhu Bhavan, Mumbai PHOTOGRAPH BY JYOTI GARIN 
The group of five or six men comprises a "leader" (i.e., mahredar), an "assistant" (i.e., bhechi or jheli), one or two "followers" (i.e., bolira or pichara). Sometimes a "buffoon" (or mashkiro), and two musicians join the group. Bhagat is a typical Sindhi narrative form that includes language, costume, headdress, songs, instruments, movements, and gestures. Dressed in a symbolic costume, the mahredar, and his bhechi chatter while the followers (pichara) simultaneously repeat and dance. Fathers do not pass on this tradition to sons. The young narrators imitate and learn while singing and dancing on all sides of the bhagat acting space spontaneously. It does not involve consciously organized training.

The session begins at nightfall, in the open air of a village square or the precincts of a temple. The spectators come from all walks of society. Formerly, bhagat gatherings lasted three consecutive nights. At joyous festivals such as marriages or fairs, they generate a sense of holiness, spread knowledge, and acclaim righteousness and social progress, including values like love, compassion, understanding, connectedness. They also commemorate the death of the saints (varsi). To this day, bhagat narrators are honored. Performances generate an atmosphere of intense communion. Participants believe that bhagats purify, on the spot, houses, and villages. The glory of Bhagat Khotaram, Satramdas, and Kanvar Ram, the bhagat par excellence, persist. Village committees (panchayats) and private individuals both organize bhagat gatherings for the peoples' delight.

As for the performance area, a perpendicular strip of space is used for the bhagat to pass (Figure 1). It divides the men from the women seated on the floor. This corridor physically brings the public closer to the performer, where he moves freely, breaks the rigidness of a stage front, and encourages spontaneity.

Sindhi folk sources suggest two definitions for the bhagat: scholarship sometimes classifies it as folk music and sometimes as folk theatre. Bhagat, among Sindhis, has a 300- or 400 -year long history. ${ }^{1}$ The term "bhagat" refers to both the narrator and the performance. It is also a title, for instance, Bhagat Kanvar Ram. It is a polysemous term derived from the Sanskrit root word bhaj, "to divide." The bhakta or bhagat is "a very pious individual" who surrenders himself to the divinity and takes part in its nature. He is the follower of bhakti, religious thought founded on the love that binds the devotee to God. N.A. Baloch's Sindhi dictionary gives four definitions for bhagat:

1 G.M. Allana, Folk Music in Sind (Jamshoro: Institute of Sindhology, 1982), 99; Lilaram Ruchandani, Sindhi Bhagat (Ahmedabad: Self-published, 1993), 25; Jetho Lalwani, Sindhi Bhagat Saili (Ahmedabad: Self-published, 1998), 11. 
- Bhagat is a Hindu ethnic group (often from the Nawabshah region and Larkana areas).

- Sanskrit bhaj "to adore" bhaktu, bhagat, and bhakti; in a broad sense, bhagat suggests a particular form of music and dance in which narrators sing and dance.

- Bhagatu langayanu or vijhanu "to make or carry out a bhagat session."

- Bhagat is a public devotional singer, a dervish, a fakir; simple, ingenious, or innocent in a broad sense. ${ }^{2}$

According to Lalwani, Hindu performers are called bhagat while Muslim performers are nachu. ${ }^{3}$ The origin of this tradition is uncertain, and the precise equivalence between these two groups remains unclear. Lalwani also adds a delightful definition: bha for bhava "emotion," ga for git or "song," and $t a$ for tal or "rhythm." Other naarrative styles related to the Sindhi bhagat are the nautanki (Uttar Pradesh), harikatha (Andhra Pradesh), bhavai (Gujarat), tamasha (Maharashtra), jatra (Bengal), and ujapali (Assam). The art is alive today (based on fieldwork 2001) and has multiple performers: Arjandas Kuvarani (in Ahmedabad); Dilip Kumar and Notandas Pritaram (in Maharashtra); Bhagwan Chawla (in Mumbai); Khanchand Kusija Mohan Jagiasi, Chunnilal, and the late Ghansham (in Ulhasnagar); and in Rajasthan, Hassaram, Kalluram, Kamal Mangnani, Kishin, Pratap Rai.

The article's main body is a translation and interpretation of a song from the tradition of bhagat. The performance translated in this paper focuses on Bhagat Kanvar Ram, the ideal bhagat, who was a simple grocer's son and who becomes a mythical character. His legend exemplifies his influence on the bhagat tradition. It offers a glimpse of the dynamics of performance and oral texts.

\subsection{Approach and Method}

The sources for this article are multiple and include articles on bhagat, popular magazines, and a study of Bhagat Kanvar Ram. ${ }^{4}$ The untimely and tragic assassination of this charismatic revolutionary produced, under the force of widespread emotion, a legend comparable to a saint's life. The vitality of this legend's narratives, with wide-ranging components, starting from oral sources, represent an irreplaceable source of information regarding the bhagat.

Bhagat combines legends with lullabies, anecdotes, and narratives passed on among Sindhis and across generations. It includes statements related to the

2 N.B. Baloch, A Comprehensive Sindhi Dictionary of Classical and Current Sindhi, Volume 2 (Jamshoro: Sindhi Adabi Board, 1981), 544.

3 Lalwani, 14.

4 Ruchandani, 1993; Lalwani, 1998; Kanhaiyalal Talreja, Amar Shaheed Kanvar Ram (Ahmedabad: Self-published, 1977). 
past: popular tales and legends and "records" them through stories. The focus here is on what bhagats orally transmit. They are testaments to past events and data on contemporary Sindhi culture (without debating the oral sources themselves). They reflect the representations and beliefs of the Sindhi enunciators and listeners.

Undeniably, this oral tradition has an artistic dimension. However, the literary value of bhagats, as a socio-cultural product, is not fixed. When written, it defies the fundamental categories of the literary genres. The bhagat is neither epic nor song. Similarly, like the idea of an author, which is crucial in written literature, it is inapplicable. Even if recitation, composition, and re-creation coincide in a bhagat performance, its narrators are neither creators nor solely performers.

Not unlike other oral literature, anonymous and collective creators get involved in its creation. "Pieces" are at the disposal of a group of narrators, and there is no planned rehearsal. The performance skill of the bhagat resides in the combination of elements well-known by the audience (Figure 2). The bhagat narrator further enhances the performance by adding novelties, and it is part of a particular performer's appealing strategy. The ongoing bhagat session involving the narrators and the public illustrates how the "pool" of Sindhi culture gets constantly enriched. This enrichment involves three kinds of exchanges: traditional (from the narrator to the public), interactive, and co-creative:

\section{"Pool" of Sindhi Culture \\ (Mental images, language, history, art, etc.) \\ The Bhagat Tradition}

(Mental text, combining skills of the different narrative genres of verbal and non-verbal folklore)

The Bhagat Narrator

Puts forward:

- text excerpts

- melodies

- gestures and movements

Performing skills

- observes the public

- adjusts (regulating reflexes)

Offers novelties

and hence modifies the tradition gradually
The Public

$\rightarrow$ Completes:

- fills in the blanks

- interprets in diverse manners according to his acquaintance with the "pool" and his sensitivity

Aesthetic evaluation

- applauds and gives banknotes

- or criticizes verbally

Creates new cultural references

$\downarrow \downarrow$

The Pool of the Sindhi Culture Enriches

FIGURE 2 Enrichment of the bhagat repertory 
It is crucial to question genre classifications in Sindhi folklore to analyze the semantics of a folk text, even if it does not provide a complete solution to issues of fundamental meaning. ${ }^{5}$ The bhagat is an "intermediary genre." On the one hand, it nestles between the various forms of Sindhi folklore, both verbal and non-verbal. On the other hand, it is a form of narration between oral folklore and written/literary tradition.

Until the twentieth century, nobody transcribed bhagat songs. The transmission was purely oral. The dates of their composition are unknown. In India, the repertories vary from state to state, and each narrator is frequently famous for a particular song. A single performer sings about fifteen excerpts in two hours, but he knows a hundred of them. Some even include Hindi and English. ${ }^{6}$

I adopt phonological transcription to record oral performance. It reflects the current state of the Sindhi language transcription and alternative forms in terms of contrasts: standard Sindhi/folklore; conventional Sindhi/dialects; Sindhi in the multilingual context of India. Like Short Message Service (sms) orthography, the transcribing of grammatical "mistakes" in a bhagat performance enlightens the linguistic evolution of Sindhi. The bhagat repertory is a continuous sound soundtrack, and intonation guided the transcription. It is akin to unrolling a parchment.

The transcript "text" translates directly from Sindhi to English. Literal translation often proved impossible since the bhagat performance is artistic. Thus, the English translation attempts to capture "essence." The narrative's outline gets preserved without omitting details. In the footnotes, I highlight some terms but without interrupting the translation flow. The translation is presented in the Latin transcription adapted to suit/reach out to a large readership.

However, transcription and translation are, by themselves, rarely sufficient. The bhagat is a complex collective event that lends itself to textualization through field observation. Such textualization aims to convey it as an oral, visual, and emotional experience. It enhances the bhagat performance as an object of study and connects performance with its documentation. It is also imperative to interpret the bhagat from the point of view of the narrator. Its contextual aspects are of primary importance in the interpretive process. For instance, the contextual parameters of a bhagat session are essential: the identities of the enunciators and the listeners, the cultural anchoring of both, the collateral activity (formerly a ritual and today, oral history), the reactions of the public, the artistic assessment, etc.

5 Parso Gidwani, Glimpses of Sindhi Bhagati (New Delhi: Sindhu Publications, 2003); Roma Doctor, "Sindhi Folklore: An Introductory Survey," Folklore 96.2 (1985): 223-233.

6 Lalwani, 1998; Ruchandani, 1998. 
For the bhagat performance, an objective was to preserve in writing the maximum number of oral features. One cannot avoid freezing oral data and transforming it into an object that the researcher can repeatedly consult when turning the pages. A characteristic of verbal exchange is an expansion in meaning. Textualization that highlights composition, performance modes, and style guides the transcription of the song in this article. ${ }^{7}$ A close textualization analysis of bhagat illustrates that it has three parts: (1) chants, (2) a combination of legends, anecdotes, etc., and (3) concluding songs of grace addressed to Jhulelal, the Indus River deity.

\subsection{Bhagat Kanwar Ram: A Short Biography}

The Sindhi community considers Bhagat Kanvar Ram a "saint." 8 The son of a grocer, he was born in 1885 in the village of Jarvar (Sukkur District, Sindh). According to the legend, he announced to his future parents, Tarachand and Tirathbai, his birth as a "chosen" being. During childhood, Bhagat Kanvar Ram attended congregations at the Hayat Pitafi Darbar. The spiritual guardian (i.e., gadisar) of this sanctuary was Mata Sahib Hassibai. She noticed his soft melodious voice and encouraged him to study music with Bhai Hassaram.

One day, Bhai Hassaram, discontented with Kanvar Ram, got angry and flung him to the ground. He complained that his teacher treated him like kalar, literally "barren land." Punning, Mata Hassibai retorted that Kanvar was not kalar but a kanvar, a "lotus" which would later spread its perfume on the province of Sindh. When Kanvar Ram became a vocal virtuoso, he left the Hayat Pitafi Darbar. Mata Hassibai, unhappy about his departure, said: "a bullet will
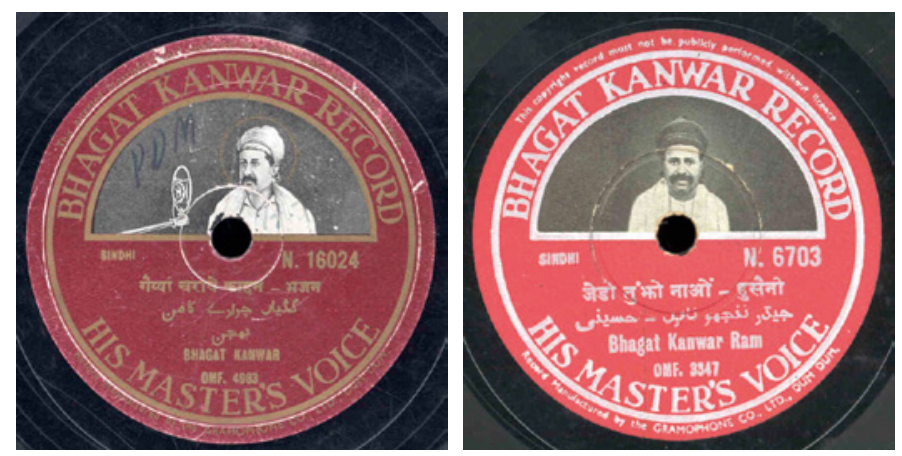

FIGURE 3 Bhagat Kanvar Ram COURTESY HMV RECORDS

7 Honko, 1998.

8 Dayal Asha, Saints of Sindh (Ulhasnagar: Chandibai Himathmal Mansukhani College, 1996), 78-81. 
pierce him!' In response, Kanvar Ram, who revered Mata Hassibai, conducted all the traditional death rites and held a poignant bhagat session on the twelfth day of mourning.

Bhagat Kanvar Ram enriched the bhagat tradition by adding a sense of worship and performance style. Wearing a long white dress, a turban, and metal anklets, he performed bhagat when the heat of the day subsided: he began to sing, recite, dance, and told popular tales until dawn. During gatherings, Bhagat Kanvar Ram received offerings. He redistributed them since he already had a livelihood (i.e., selling boiled peas in the streets). He gave the offerings to the needy or used them to build "community host houses" or dharam-shalas. Hindus, Muslims, untouchables, the influential and the weak, and even gangsters attended Kanvar Ram's bhagat sessions without discrimination. Thus, through bhagat, he defended the values of humanism, love for a neighbor, unity, patriotism, and social progress. All three concepts hold a central place in his performances. Famous, he traveled in various parts of Sindh, particularly during "the death celebration of the saints" or varsi. He played a crucial role in popularizing the bhagat tradition.

He married in 1903 and had a son (i.e., Pessuram), and two daughters (i.e., Bhagwantibai and Kalawantibai). Six years later, his wife died. He then got married a second time, to Gangabai. On November 1, 1939, two fanatics killed him at the Ruk station, where an immense crowd had come to welcome him (as was customary throughout his travels). He was 55 years old, and Mata Hassibai's prediction came to fruition.

\subsection{Translation}

Bhagat narrators very often mention Kanvar Ram's holiness, his miracles, and performances. ${ }^{9}$ His Master's Voice published recordings of his kafi and bhajans. ${ }^{10}$ Among his most well-known songs, bhagat narrators cite the following:

- Nale Alakha je bero tari muhinjo or "In the name of the Eternal One, allow my boat to navigate" (the Dawn Melody).

9 For a complete list of Kanvar Ram's discography, see Jyoti Garin, "Le Bhagat, une Tradition Orale Sindhie," Ph.D. diss., Institut National des Langues et Civilisations Orientales, 2005 (http://www.theses.fr/2005INALoo15 [accessed August 28, 2021]).

10 A poetic form, it has a succession of four lines and a refrain of two lines. The first three lines rhyme together and the last with those of the refrain, according to the following structure: AAAB BB CCCB BB, etc. There are two different etymologies for this term: qafiya "rhyme or poem" and kafa Arabic "rattle." In Sindh, the fakirs and Sufis frequently travel the streets with a rattle to beg for alms. It is a form of poetry that the Sindhi people cherish in the countryside. 
- Au kanga kari galhi munsan tani maruaraniji or "Come crow, speak of the Marus" (the Maru Melody).

- Ram sumar prabhata, mere manu or "Remember to name Ram at dawn, my spirit" (the Dawn Melody).

- Kiyan rijhayan, kiyan parachayan tokhe, or "How to cherish you, how to console you."

- Jedo tuhinjo nao or "To the measure of Your name."

- Milana hove to milu or "If you want to meet, then come."

- Prata samay, Mohana or "At dawn, Mohan."

- Loli lala nu or "I sing a lullaby to the little one."

- Sacho Sain Satram or "The true Swami Satram."

In addition to these songs, others illustrate how Bhagat Kanvar Ram lives in the memories of current bhagat narrators. This paper focuses on one example that narrates the legend of Bhagat Kanvar Ram's life as a poor boy who becomes the best and the greatest bhagat. Like in folktales and legends, his life involves encounters and ordeals. Evil gets reversed and transforms into a divine blessing. In the song, a critical refrain resonates: destiny smiled upon Swami Kanvar Ram.

\section{The Legend of Bhagat Kanvar Ram ${ }^{11}$}

\section{In Sindhi}

Music

Kosa kohara khani haliyo bhaga khulya Sain Kanvar Rama ja (Allah)

kosa kohara khani haliyo

bhaga khulya Sain Kanvar Rama ja

o diyan paise men panu ta bhare

hoka Dindo haliyo Rama nama ja

o diyan paise men panu ta bhare

hoka dindo haliyo Rama nama ja

kosa kohara khani haliyo

bhaga khulya Sain Kanvar Rama ja (Allah)

kosa kohara khani haliyo

bhaga khulya Sain Kanvar Rama ja

Music

mithi bolindo haliyo boli

11 As none is currently accepted, there is no attempt in this article to propose a scientific transliteration of Sindhi. 
jite lathala santana ji toli (Allah)

mithi bolindo haliyo boli

jite santana ji toli

mithi bolindo haliyo boli

jite lathala santana ji toli

avazu vayo kana te

nena khulya Sain Satrama ja

avazu vayo kana te

nenaa khulya Sain Satrama ja (Allah)

kosa kohara khani haliyo

bhaga khulya Sain Kanvar Rama ja (Allah)

kosa kohara khani haliyo

bhaga khulya Sain Kanvar Rama ja

Music

are bhai Rama nama ja mithira kohara

Sain Kanvar Ram kohara khani kare Sain Satramdas sahibajana khe (beli) mana'e aya ahin Jarvarana je shahara man

\section{In English}

\section{Music}

He moved on carrying with him hot chickpeas, ${ }^{12}$

destiny smiled upon Swami Kanvar Ram (Allah)

he moved on carrying with him hot chickpeas

destiny smiled upon Swami Kanvar Ram

I sell a handful for a paisa ${ }^{13}$

in the name of Ram, he cried as he passed by

a handful for a paisa

in the name of Ram, he cried

he moved on carrying with him hot chickpeas

destiny smiled upon Swami Kanvar Ram (Allah)

he moved on carrying with him hot chickpeas

destiny smiled upon Swami Kanvar Ram

Music

he walked speaking sweet phrases

where the group of saints rested a while (Allah)

he walked speaking sweet phrases

where the group of saints rested awhile

12 Kohira is millet, peas, or chickpeas boiled and sold in the streets.

13 Paper bowls. 
he walked speaking sweet phrases

where the group of saints rested awhile

the call reached Swami Satram's ears

Swami Satram opened his eyes (Allah)

the call reached Swami Satram

Swami Satram opened his eyes (Allah)

he moved on carrying with him hot chickpeas,

destiny smiled upon Swami Kanvar Ram (Allah)

he moved on carrying with him hot chickpeas

destiny smiled upon Swami Kanvar Ram

Music

hey brother, in the name of Ram, here are some sweet chickpeas!

Swami Kanvar Ram taking his hot chickpeas, he goes towards Swami

Satramdas Sahib

(friends) in the Jarvar town

\section{In Sindhi}

Kanvar Rama ji mata cavethi - bachira Kanvara, (beli) adhu seru khani tokhe kohara radhe dyan

Vani vikini a

ba tre paisa mili pavanda

Sain Kanvar Ram agya vathi kare, uhe kohara khani kare vikirani la'e pyo vane

cavando pyo vane: Rama nama ja mithira kohara kha'o

mithiro avazu

Rama nama ja mithira kohara

Sain Satramdas Sahibajana je kana the parlau payo ahe

santu nikri bahar ayo

acanu san gale lagayo

santu nikri bahar ayo

acanu san gale lagayo

(o) caya'in: lala sakhi bachira

ayo vethala kahare ganva ja?

(o) lila sakhi bachira

ayo vethala kahare ganva ja?

kosa kohara khani haliyo

bhaga khulya Sain Kanvar Rama ja (Allah)

kosa kohara khani haliyo

bhaga khulya Sain Kanvar Rama ja

Music

Sain Satramdas cavetho: bacha Kanvara 
are aba tuhinjo nalo cha ahe? kahare gotha ja vethala ayo? Ahari mithiri boli

vari cavetho: Rama nama ja mithira kohara

are aba, tuhinjo nalo cha ahe?

Kanvar Ram cavetho: muhinja babala

nav Kanvar man sadayan

putu Tarachanda jo ahiyan (Allah)

nav Kanvar man sadayan

putu Tarachanda jo ahiyan

(Allah), o muhinja datara

o Jarvaru muhinjo ganvu

ayun naukara tuhinje nanva ja

\section{In English}

Kanvar Ram's mother says: child Kanvar, (friends) I will cook a pound of chickpeas

go and sell them

that will get us two or three paisas

Swami Kanvar Ram takes leave, takes the chickpeas, and leaves to sell them

while passing, he says: in the name of Ram! eat soft peas

what a melodious voice

in the name of Ram! [here] are soft peas

the cry reached Swami Satramdas Sahib's ears

the saint came out

and at once embraced him

the saint came out

and at once embraced him

he says: generous child

which village are you from?

generous child

which village are you from?

he moved on carrying with him hot chickpeas

destiny smiled upon Swami Kanvar Ram (Allah)

he moved on carrying with him hot chickpeas

destiny smiled upon Swami Kanvar Ram

Music

Swami Satramdas says: child Kanvar

little father, what is your name? which village are you from? what sweet phrases ...

at that time, he says: in the name of Ram! sweet peas 
oh, little father, what is your name?

Kanvar Ram says: my father

they call me Kanvar

I am Tarachand's son (Allah)

they call me Kanvar

I am Tarachand's son

(Allah) oh my benefactor ${ }^{14}$

Jarvar is my village

we are the servants of Your name

\section{In Sindhi}

Jarvaru a muhinjo ganvu

ayun naukara tuhinje nanva ja (Allah)

kosa kohara khani haliyo

bhaga khulya Sain Kanvar Rama ja (Allah)

o dyan paise men panu ta bhare

hoka Dindo haliyo Rama nama ja (Allah)

kosa kohara khani haliyo

bhaga khulya Sain Kanvar Rama ja

Music

Sain Satramdas sahibajan mithiro galayanu budhi kare mohitu thi paya santana ji jeka saji toli nindra men sumi pe'i

avaaza te sabhe'i nikri bahar aya

Sain Satramdas sahibajana ditho sajioya toliya khe

Kanvar Rama khe cavantha: aba, hiyana hoko ta de'i dekhari

Kanvar Ram cavetho: muhinja sain, Rama nama ja mithira kohara kha'o

Rama nama ja

mithira kohara kha'o

Sain Satramdas cavetho: aba, kohara, aba, bacha Kanvara, ihe kohara

sadha sabha'i kha'indai,

pani piyandai, na pa'i dindai (Allah)

sadha sabha'i kha'ndai

pani piyandai, na pa'i dindai

muhinja Malika,

ahe siru bi sadhana sadike,

ayun naukara tavanje nanva ja (Allah)

Kanvar Ram cavetho: muhinja Malika,

ahe siru bi sadhana sadike,

ayan naukara tavanje nanva ja (Allah)

Stated respectively. 
kosa kohara khani haliyo

bhaga khulya Sain Kanvar Rama ja (Allah)

kosa kohara khani haliyo

bhaga khulya Sain Kanvar Rama ja

Music

\section{In English}

Jarvar is my village

we are the servants of Your name (Allah)

he moved on carrying with him hot chickpeas

destiny smiled upon Swami Kanvar Ram (Allah)

I sell a handful for a paisa

in the name of Ram, he cried as he passed by

he moved on carrying with him hot chickpeas

destiny smiled upon Swami Kanvar Ram

Music

hearing the soft phrases, Swami Satramdas Sahib is enchanted the group of saints who was sleeping

awake to the cry, come out

Swami Satramdas Sahib looks at the whole group

he says to Kanvar Ram: little father, repeat your phrase

Kanvar Ram says: my Masters, eat sweet chickpeas in the name of Ram! in the name of Ram!

eat sweet chickpeas

Swami Satramdas says: little father, chickpeas, little father, child Kanvar,

the peas

all the ascetics will eat them

drink water, but to none of them will give you a paisa (Allah)

all the ascetics will eat them

drink water, but none of them will give you a paisa

my Master

this head also is an offering to the ascetics

we are the servants of Your name (Allah)

Kanvar Ram says: my Master

this head also is an offering to the ascetics

we are the servants of Your name (Allah)

he moved on carrying with him hot chickpeas

destiny smiled upon Swami Kanvar Ram (Allah)

he moved on carrying with him hot chickpeas,

destiny smiled upon Swami Kanvar Ram

Music 


\section{In Sindhi}

kohara sadhana sabhini khada jeke Kanvar Rama anda (Allah) kohara sadhana sabhini khada, jeke Kanvar Rama anda vaya kohara tuhinja adhu thyi Vishinu kama kare vayo ama ja (o muhinja rana, muhin ja rana, muhinja ranara, muhinja rana) vaya kohara tuhinja adhu thi Vishinu kama kare vayo ama ja Kanvara, tuhinje koharana ja aju kana vya pokhi ji Kanvara, tuhinje koharana ja aju kana vya pokhi ji umaru sari pyo lune o umaru sari je lune o ta bi sangu na vendu sokhi ji

Satramdas du'a tho kare: bacha Kanvara, tuhinja kohara aghamiji vaya kosa kohara khani haliyo

bhaga khulya Sain Kanvar Rama ja (Allah)

kosa kohara khani haliyo bhaga khulya Sain Kanvar Rama ja o dyan paise men panu ta bhare kosa dindo haliyo Rama nama ja kosa kohara khani haliyo bhaga khulya Sain Kanvar Rama ja (Allah) kosa kohara khani haliyo bhaga khulya Sain Kanvar Rama ja o dyan paise men panu ta bhare kosa Dindo haliyo Rama nama ja o dyan paise men panu ta bhare kosa Dindo haliyo Rama nama ja kosa kohara khani haliyo bhaga khulya Sain Kanvar Rama ja (Allah) kosa kohara khani haliyo bhaga khulya Sain Kanvar Rama ja 


\section{In English}

all the sadhus ate the chickpeas

which Kanvar Ram had brought (Allah)

all the sadhus ate the chickpeas

which Kanvar Ram had brought

your peas decreased by half

so Vishin says: ${ }^{15}$ thus, he served the people

(oh, my king, my king

my king, my king) ${ }^{16}$

your peas decreased by half

so Vishin says: thus, he served the people

now Kanvar

you have sown the seeds of your peas

now Kanvar

you have sown the seeds of your peas

all life long, you will harvest

even if all life long you harvest

the pods will not dry up

ah!

Satramdas praises [Ram] and says: child Kanvar, your peas are accepted he moved on carrying with him hot chickpeas

destiny smiled upon Swami Kanvar Ram (Allah)

he moved on carrying with him hot chickpeas

destiny smiled upon Swami Kanvar Ram

I sell a handful for a paisa

hot chickpeas, in the name of Ram

in the name of Ram, he cried as he passed by

destiny smiled upon Swami Kanvar Ram (Allah)

he moved on carrying with him hot chickpeas

destiny smiled upon Swami Kanvar Ram

I sell a handful for a paisa

in the name of Ram, he cried as he passed by

I sell a handful for a paisa

in the name of Ram, he cried as he passed by

he moved on carrying with him hot chickpeas

destiny smiled upon Swami Kanvar Ram (Allah)

he moved on carrying with him hot chickpeas

destiny smiled upon Swami Kanvar Ram

15 The composer.

16 Another form of address to the public, like "friends." 


\section{In Sindhi}

Sain Kanvar Rama ja kohara aghami vya

Sain Satramadas aju bachire Kanvara khe vathi kare

Tarachanda vati aya ahin

Sain Kanvar Rama ji banha vathi kare

pahinje Raharkiya men tha vathi acan

aju Sain Kanvar Rama je mathan Satramdasa ji mehara thi a (beli) bhagatyun karanu sekharintha

(sabha'I cha'o Ram)

Music

(a) disi jori mazedar

Kiyan pe'i mauja macha'e

disi jori mazedar

dadhi theahethi, dadhi vane pe'i

disi jori mazedar

kiyan pe'i mauja macha'e

Satram Sain Kanvar Ram

rasa racha'e

Satiram Sain Kanvar Ram

rasa racha'e

shahara Shikarpura men

chadya'un rangiro racha'e

hiya galhi budho tavhin

pyar dhyan laga'e

aha jori a

dadhi vane pe'I, dadhi suthi a

Music

ca'i kafi Kavar Rama

bola bole pyo mithira

ca'i kafi Kavar Rama

bola bole pyo mithira

hika bhena, o hika mata

hika amaru kayo sadu haka ${ }^{17}$ putira

hiya topi kalabaza ji

pa'e ta tun bachira

17 Inaudible in recording. 


\section{In English}

Kanvar Ram's peas are accepted

today, Swami Satramdas accompanies the child

on the way to Tarachand

taking Swami Kanvar Ram by the arm

he takes him to Raharki

today, Satramdas's grace takes care of Swami Kanvar Ram

(friends) he teaches him how to perform the Bhagat

(every one, pronounce the name of Ram!)

Music

look at the happy pair

how jubilant they are

look at the happy pair

how they blend together, how charming they are

look at the happy pair

how jubilant they are

Swami Satramdas

and Kanvar Ram dance with joy

Swami Satramdas

and Kanvar Ram dance with joy

in the town of Shikarpur

they brought colour

listen to this phrase carefully

with devotion

ah, the happy pair

how they blend together, how charming they are

Music

ah!

Kanvar Ram recited the kafi

he pronounced sweet phrases

Kanvar Ram recited the kafi

he pronounced sweet phrases

ah, a sister, yes, oh, a mother

mummy called: son!

child, come and wear

the performer's hat ${ }^{18}$

18 Thus, symbolically, Kanvar Ram is initiated into the bhagat tradition. 


\section{In Sindhi}

hiya topi kalabaza ji

pa'e ta tun bachira

bhagavan kando sada

jiyanden tun lala gulira

datar kando sada

jiyanden tun lala gulira

topi vathi chadi

Kanvara lika'e

aha jori a

dadhi vane pe'i, dadhi suthi a

Music

Shikarpura je shahara men

Sain Kanvar Ram Sain Satramdas Sahibajana san pandhre sale je umaru men pahanyo

pahanyo bhagatu karanu vya ahin

hazare khalqa a

char premi uthi kare cavantha: muhinja Sain hina bachire khe ando athava (vo, vo)

hina bachire khan bi hikiro bhajan cavayo

Sain Satramdas Sahibajan Kanvar Rama khe sadu tha kani: bacha Kanvara, hikiro bhajan cha'o

Hedan Sain Satramdas, hedan Sain Kanvar Ram

(beli) mauja lagi pe'i a

manhu cavantha: aba hode ta nihari

disi jori mazedar

kiyan pe'i mauja macha'e

Music

hikiri mata jo sadu kayo Sain Kanvar Rama khe

uha topi pahinje puta je la'e thara'i hu'i

mithiro ragu budhi kare (beli) vicharu mata kayo

makhe Sayinya ganja dina ahen

cha ta mithiro Kanvar

(beli) ga'etho mithiro

cho na iha topi ghura'e dyan bachire mithire Kanvara khe

makhe Sayinya ganja dina ahen

cho na man pahinje puta khe bi topi thara'e dindasi

Kanvar Rama khe mata sadu kayo

Sayinya Kanvar Rama cavetho: ama tuhinjo Kanvar baciro huzuru a mata cavethi: puta Kanvara hiya topi pa'e 


\section{In English}

child, come and wear

the performer's hat

may God grant

long life to you, dear flower

may the Giver grant

long life to you, dear flower

Kanvar Ram took

the hat on the sly

ah, the happy pair

see how they blend together, how charming they are

Music

in the town of Shikarpur

Swami Kanvar Ram went to present his very first Bhagat session

at the age of fifteen, beside Swami Satramdas Sahib

thousands of people are there

there, four admirers rise and say: my Master, you have brought this child so let the child sing a bhajan

Swami Satramdas Sahib calls Swami Kanvar Ram: child Kanvar, then, sing a bhajan

Swami Satramdas Sahib is here, Swami Kanvar Ram is there

(friends) there is delight

people say: father, look there ...

look at the happy pair

see how they blend together, how charming they are

Music

a mother called Swami Kanvar Ram

this hat, she had got it tailored for her son

by listening to his melodious song (friends) the mother said to herself:

the Master gave me a lot

how sweet he is, Kanvar

(friends) he sings so well

why not give this hat to the lovely child Kanvar

the Master gave me a lot

why not get another hat tailored for my son?

the mother called Kanvar Ram

Swami Kanvar Ram says: mother, your child Kanvar is here the mother says: son, Kanvar, just wear this hat 


\section{In Sindhi}

Sain Kanvar Ram samu jo nihare

Sain Satramdas Sahibajan niharintha

(beli) disi kare mata khe ca'etho: man vathaintho

(beli) puthi de'i bhihiji vyo

Sain Satramdas nihare pyo

hedan mata cavethi: putira vathu

mata vathaintho

santani hode niharyo

bachire Kanvar Rama uha topi varti

Sain Kanvar Rama topi vathi khise men vidhi

mata cavethi: puta Kanvara, shabas hujei, makhe ta pa'e ta dekhari, disan tha'e ta athi

Sain Kanvar Ram hua topi pati a

jani ta thayala i santa je mathe ji

mata khan danhan, nikri ve'i: puta Kanvara

o bhagvan kando jiyanden

sada lala tun gulira

topi vathi Kanvara

chadi ute lika'e

topi vathi Kanvara

chadi ute lika'e

disi jori mazedar

kiyan pe'i mauja macha'e

Music

Sain Satramdas Kanvara khe cavetho: bacha Kanvara, hane pahinje gotha vanu

bhagatyun bi konani

je bhagatyun thiyun tokhe ghura'e vathandumi

(beli) Satiguruni ji agya vathi kare Sain Kanvar Ram pahinje mulku Jarvarani men tho ace

aci pita khe pere pa'i, mata khe pere pa'i

banha khan vathi kare, andar vathi ayo a, ca'etho: ama hede ta nihari

mata topi dithi, sundar topi

garibi halu, mata cavethi: puta Kanvara (beli) kahinji khani a'en?

mata ja etra akhara cavanu, Kanvar Ram cavetho:

ama, man bhagatyuni te vayumi

Shikarpura je shahara men hikiri ma'iya sadu kayo

hiya topi dini atha'in 
pa'e kare mau khe cavetho: ama disu ta sahin, tha'e ta athi?

hede ta nihari, o muhinji ama, disu ta sahin

mata cavethi: putra Kanvara, bhala santani khe khabara ahe?

mata ja etra akhara budhi kare Sain Kanvar Ram cavetho: ama santani vati jeka

bi shaha aceti, bhagatu bandi kare virahe tha chadini

\section{In English}

Swami Kanvar Ram looks in front of him

Swami Satramdas Sahib is watching him

(friends) on seeing him, he says to the mother: I will take it

(friends) he turns round

Swami Satramdas is still watching him

the mother says: son, just take it

mother, I will take it

the saints faced on the other side

child Kanvar took the hat

Swami Kanvar Ram took the hat, put it in his pocket

the mother says: child Kanvar, congratulations, put it on, let's see whether

it suits you

Swami Kanvar Ram wore the hat

as if it were cut for the saint

the mother exclaimed, child Kanvar

may God grant

long life to you, dear flower

Kanvar took the hat

hid it at once

Kanvar took the hat

hid it at once

look at the happy pair

see how they blend together, how charming they are

Music

Swami Satramdas says to Kanvar: child Kanvar, now go back to your village

these days, there are no Bhagat sessions

if they occur, I will call you

(friends) while taking leave from the holy Master, Swami Kanvar Ram returns in the

he bows before his father, he bows before his mother [Jarvar] town 
taking her by the arm, he enters and says: mom, just look at this the mother saw the hat

the mother who knows her poverty, says: son Kanvar (friends) whose hat is this?

[the mother hardly pronounced these words that Kanvar Ram says: mom, I went to perform Bhagat sessions in Shikarpur town, a woman called me it is she who gave me this hat

he takes it and says to his mother: mom, just have a look, it suits me fine, isn't this?

look here, ah mom, just have a look

the mother says: child Kanvar, by the way, do the saints know about it? on hearing these words, Swami Kanvar Ram says: mom, everything that the saints

collect at the end of the Bhagat sessions, they just distribute it

\section{In Sindhi}

ahari shaha man kiyan vinayan

lika'e rakhu jadahan jadahan bhagatyun thiyani, tadin tadin pa'e pyo vendumi mata thi moha je vasu uha topi lika'e rakhi a para Yara ji qudrata o dihan thora thya Kanvara khe bukhar thi payaro o dihan thora thya

Kanvara khe bukhar thi payaro kani ke'i davaun pya, para farqu na payaro hutan Tarachanda dili men vicaru hi kayaro ahe jahinjo dinalu tani vatu chade acan baciro Satram Sainya je dara te aya puta khe khana'e disi jori mazedar dadhi vane pe'i, disi jori a

Music

Sain Kanvar Ram (beli) bukhara men gashu laga pya ahen Sain Satramdas sahibajan (beli) vacanu pya ta vathan 
Sain Kanvar Ramaja mata-pita bacire khe khana'e aya ahen rohi kare, cavantha muhinja malika, muhinjo baciro, jiyan tavhan vatan ayo a, aharo ta bukharu thyo athasi

jiyan dava ka'i, tiyan dukhu vanetho vadhando

dinalu bi tavhanjo, dava bi tavhan kandau

Sain Satramdas sahibajan budho anabudho kare vyo

hiku dinhu guziryo, ba dinha guzirya

triyen dihare prabhati je samay men

Kanvar Rama ji mata aju roheti zaraun zar

uhe gorha kirani Kanvar Rama je galani te pya pavani

Kanvar Rama ji akhu khuli

mata khe ruando disi kare ca'etho: muhinji ama, santani je dara te, muhinja satguru dayalu

\section{In English}

this beautiful object, how to lose it?

hide it

each time that a Bhagat session will take place, I will wear it for the occasion

the mother succumbed to attachment

she hid the hat

but who knows the nature of the Friend ...

a few days later

Kanvar Ram has fever

a few days later

Kanvar Ram has fever

many remedies were given

but nothing changed

so Tarachand thinks

he thinks:

he who gave us the child ${ }^{19}$

I will take back the child to him

he went to Swami Satram's door

carrying his son

look at the happy pair

see how they blend together, how charming they are

Music

19 Though, according to the legend, it was Bhagat Khotaram who announced Kanvar Ram's birth. 
Swami Kanvar Ram (friends) is exhausted by the fever

Swami Satramdas (friends) is uttering the Word

Swami Kanvar Ram's parents carry the child

in tears, they say: my Master, my child, since he took leave from you, the temperature

though drugs were administered, the pain increases [suddenly shot up it is you who gave him to us you who will look after him

Swami Stramdas ignored the call

one day passes, two days pass

the third day, at dawn, today

Kanvar Ram's mother is still crying

the tears fall on Kanvar Ram's cheek

Kanvar Ram opened his eyes

on seeing his mother crying, he says: my mother, at the saints' doorstep! my Satguru is compassionate

\section{In Sindhi}

muhinje santani je dara te ruanda aya, khilanda vaya

tun vari roheti pe'i

danha kare cavethi: baca Kanvara, aju tre dinhara thya ahen santani je dara te

(beli) ajun kayun ahen, nizaryun kayun ahen

(beli) munhu'i natha diyani

ahari ka galti thi va'i a

o muhinja bacira (beli) mukhe aram kiyan indo cho ta piyu mau putra

khe dukhu na dindo

sab kuchu pahinje sira te sahando

o muhinja lala bacira, pe'i thi dahun karyan satigurani khe

mana ji pukara budhani

Sain Kanvar Ram, (beli) ro'i kare mata khe cavetho: parvah na kari, muhinja satiguru dayalu ahin

ro'i kare aju pahinje satigurani khe prarthana tho kare

(beli) ajho na' tham asiro

ajho na' tham asiro

(o) muhinji jhugi jhale nathi

sartyun Shahu Latifu cave

ahe halu ta muhinjo hi

(vo, vo) hane 'dhola dhakana thi

(o beli) muhinje hinan madayun jo

(bhalo) 
vah muhinja nimani ja mana,

o, e Hari

Kanvar Rama jo prarthana ka'i

(beli) pyara ja sadira budhi kare satiguru jo langhanitha

Sain Kanvar Rama jo ditho pahinje satigurani khe, hatha jore, ho bahun

badhi

ho pere pe'i Kanvar Rama cayo

ahyan man bimar, munte daya karyo dili san

ahyan man bimar, munte daya karyo dili san

ahyan nandhiro man bar

Music

Satramdas cavetho: re Kanvara, chatho caven tote daya kayan, chaji tote daya kayan?

Kanvar Rama Sain ro'i kare cavetho: muhinja malika

o muhinjo dukhiro lahyo

o muhinjo malika, munte daya kayo

\section{In English}

at the saint's doorstep, they came crying and left laughing and you are crying!

complaining, she says: child Kanvar, today I have been here for three days at the saint's doorstep

(friends) I have made sincere prayers, begged

(friends) he did not even turn to see

surely, something has gone wrong

oh my child (friends) how to remain calm? father and mother will not let a son suffer

they take everything upon themselves

my dear child, I pray to the Satguru

that he may listen to my heart's call

Swami Kanvar Ram (friends) in tears, he says to his mother: do not worry my Satguru is compassionate

in tears, today, in front of his Satguru, he implores

(friends) I have neither refuge, nor protection

I have neither refuge, nor protection

my hut does not hold

thus Shah Latif says: ${ }^{20}$ friends

20 The composer, Shah Abdul Latif (1689-1752), was a Sufi from Sindh. Hindus and Muslims consider his Shah jo Risalo a masterpiece of Sindhi literature. 
this is my state

Friend, now become the one who covers

(oh friends) my faults

(may the good come forth)

congratulations, Thou paragon of humility

(oh Hari)

as soon as Kanvar Ram called

(companions) passing by, Satguru hears this call of gentleness

when he saw his Satguru, Kanvar Ram, arms joined, hands folded

prostrating, Kanvar Ram says:

I am unwell, have mercy on me

I am unwell, have mercy on me

I am only a little child

Music

Satramdas says: hey, you say have mercy, what kind of mercy?

weeping, Swami Kanvar Ram says: my Master

remove my pain

my Master, have pity on me

\section{In Sindhi}

Satiram Sainya cayo: to ta kayo na vicar

to ta kayo na vicar

vicar kona kayu, aju tho caven, muhinjo dukhu lahe

para puta Kanvara yad rakhijain

ho, jeke topi lika'inda

sada hunda bimar

ho, jeke topi lika'inda

sada hunda bimara

je vacanu den Kanvara

chadu dukhiro mita'e

je vacanu den Kanvara

chadu dukhiro mita'e

aha jori a

dadhi vane pe'i, dadhi suthi a

Music

Sain Kanvar Ram hatha jore cavetho: muhinja malika, jiyan hukumu kandava tiyan kandomava

para yara, muhinjo dukhiro la'e

Sain Satramdas cavetho: aba, avala iha topi khani a, jahin men dukhu a, 
jahin men bukharu a

Sain Kanvar Ram mau de niharyo

mau cavethi: puta Kanvara, man khani a'i ahyan

mata topi khani Kanvar Rama khe dini a

Sain Kanvar Ram topi khani kare pahinje satigurani khe tho dye

Sain Satramdas cavetho: puta Kanvara, hode samu nihari, o mastano vetho'thi

hina mastane men Maliku vase, (beli) rakhijen tun Tani san nato

(beli) mastane khe topi pa'e Sain Kanvar Ram ayo, satigurani je caranani te hathu rakhiya'in

satigurani ji nazar thi va'i

je nazar thi ve'i po'e kaharo bi dukhu hundo ta dur thi vendo

Satramdas cavetho: puta Kanvara, hane jiyan man cavain, je muhinje vacana te tho

halen ta asan bi tosan vacanu tha karyun ta

puta Kanvara jesta'in siju candu tara ahen testa'in duniya pe'i tuhinja guna ga'indi

Sain Kanvar Ram perante kiri kare ca'etho: muhinja murshida, o muhinja satiguru

baki mukhe cha khape, jiyan cavandava man tiyan kandomava

he dasu Kanvar tavhanjo naukaru hazuru ahe

\section{In English}

Swami Satramdas says: you did not even ponder

you did not ponder

you did not ponder and today you say, remove my pain

but child Kanvar, remember

they always will be sick

those who hide the hat

they always will be sick

those who hide the hat

if you give me your word

then I will remove the pain

if you give me your word

then I will remove the pain

ah, the happy pair

see how they blend together, how charming they are

Music

Swami Kanvar Ram, hands folded, says: my Master, I will follow your orders 
but friend, remove this pain

Swami Satramdas says: little father, to start with, bring the hat in which reside

Swami Kanvar Ram turns towards his mother [pain and fever

mother says: son, I have brought it

the mother gave the hat to Kanvar Ram

Swami Kanvar Ram takes the hat and hands it over to his Master

Swami Satramdas says: son Kanvar, look over there, in front of you stands the Enchanted One ${ }^{21}$

the Master lives in the heart of the enchanted ones, (friends) keep in touch with Him

(friends) Swami Kanvar Ram put the hat on the Enchanted One, he prostrated

Satguru's glance swept across [Kanvar Ram] [at the feet of the Master if the glance sweeps across, all pain will disappear

Satramdas says: son Kanvar, here's all I have to say, if you listen to my words

[then I also give you my word

son Kanvar, as long as the sun will remain, the moon and the stars, the world will talk

about your virtues

Swami Kanvar Ram says while prostrating at his feet: my spiritual guide, my satguru, what else do I need, I will do what you say

Kanvar, this slave, your servant, is here

\section{In Sindhi}

Sain Satramdas ca'etho: puta Kanvara

de vacanu iyo

kadhain pa'i na khananden

jeki mila'i tokhe

Dhaniya nale pyo dinden

je vacanu khananden

Vishina amar thinden

je vacanu khananden

Vishina amar thinden

asisa asanji

tun vasanden ain vadhanden

21 Likely the saint of the sanctuary. 


\author{
asisa asanji \\ tun vasanden ain vadhanden \\ dino vacanu Kanvar Rama \\ pahinje sira khe nima'e \\ aha jori a \\ dadhi vane pe'i, dadhi suthi a \\ disi jori mazedar \\ kiyan pe'i mauja maca'e \\ disi jori mazedar a \\ dadhi thahethi, dadhi vane pe'i \\ disi jori mazedar \\ kiyan pe'i mauja maca'e \\ Satiram Sain Kanvar Ram \\ rasa raca'e \\ Satiram Sain Kanvar Ram \\ rasa raca'e \\ shahara Shikarpura men \\ chadyaun rangiro raca'e \\ hiya galhi budho tavhin \\ pyar dhyan laga'e \\ aha jori a \\ dadhi vane pe'i, dadhi suthi a
}

\title{
In English
}

Swami Satramdas says, son Kanvar

promise me

you will not take even one paisa

all that you will receive

you will bestow it in the name of the Lord

if you promise me

thus Vishin says: you will be immortal

if you promise me

thus Vishin says: you will be immortal

here are my blessings

you shall live and you shall grow

here are my blessings

you shall live and you shall grow

Kanvar Ram promised

bowing his head 
ah, the happy pair

how they blend together, how charming they are

look at the happy pair

how jubilant they are

look at the happy pair

how they blend together, how charming they are

look at the happy pair

how jubilant they are

Swami Satramdas and Kanvar Ram

dance with joy

Swami Satramdas and Kanvar Ram

dance with joy

in the town of Shikarpur

they brought colour

listen to this phrase carefully

with devotion

ah, the happy pair

how they blend together, how charming they are!

\section{Final Comments}

Bhagat performances are a Sindhi community feature in India and its diaspora. Its narrators are generally Hindu and Sindhi speaking. It is impossible to imagine a bhagat gathering in another language and for another public. The form of the narration, the fragmentations, and interruptions would be incomprehensible to the uninitiated audience. The boundary between popular literature and other literary works gets blurred. By doing so, the performers preserve the memory of Bhagat Kanvar Ram and connect the community to its past.

The repertory of a bhagat reveals distinct levels of significance. Bhagat Kanvar Ram influences these levels, both in content and style but also socially and symbolically. At the social level, values such as humility, generosity, sweetness, and love predominate. Spiritual and mythical dimensions also are symbolically part of these performances. In their collective minds, Sindhi audiences make connections to Bhagat Kanvar through divine grace symbols. Most incidents narrated during a bhagat session about Bhagat Kanvar Ram's life, both the dramatic and negative, reflect divine grace. By citing his example frequently in bhagat sessions, contemporary performers collectively remind 
audiences of his virtues. ${ }^{22}$ They invoke him as an appealing strategy. This strategy extends to style issues: many current narrators dress like Kanvar Ram (long white dress, turban, and anklets) and reproduce his words and purported gestures. People regard him as the ultimate authority and the father of the bhagat oral tradition. Individuals index and evoke a shared "pool" of Sindhi culture that binds performers and audiences alike by citing and mimicking him. This pool represents an irreplaceable source of information about bhagat. In this sense, bhagat strongly represents Sindhi culture, and its performers are "oral historians."

22 Examples include "Destiny smiled upon Swami Kanvar Ram; the saint came out and at once embraced him; you have sown the seeds of your peas, all life long, you will harvest. Even if all lifelong you harvest, the pods will not dry up; Kanvar Ram's peas are accepted. Today, Swami Satramdas accompanies the child on the way to Tarachand. Taking Swami Kanvar Ram by the arm, he takes him to Raharki. Today, Satiramdas's grace takes care of Swami Kanvar Ram. (Friends) he teaches how to perform the bhagat; Satramdas says: son Kanvar, here's all I have to say, if you listen to my words, then I also give you, my word. Son Kanvar, as long as the sun will remain, the moon and the stars, the world will talk about your virtues - Satguru's glance swept across [Kanvar Ram]; thus, Vishin says: you will be immortal, here are my blessings, you shall live, and you shall attain self-realization." 